\title{
Antioxidant Phenolic Constituents from the Leaves of Acer ginnala var. aidzuense
}

\author{
Masato Watanabe ${ }^{1}$ and Hari Prasad Devkota ${ }^{1,2^{*}}$ \\ 'School of Pharmacy, \\ 2Program for Leading Graduate School, HIGO Program, Kumamoto University, \\ 5-1 Oe-honmachi, Chuo-ku, Kumamoto, 862-0973, Japan.
}

\begin{abstract}
Acer ginnala Maxim. var. aidzuense (Franch.) Pax was reported recently from Kumamoto Prefecture, Japan after many years. Thus, the main objective of present study was to identify the chemical constituents in the leaves of title plant and evaluate the antioxidant activity of the extract and isolated compounds. Gallic acid (1), methyl gallate (2) and acertannin (3) were isolated from the $70 \% \mathrm{MeOH}$ extract of the leaves. The extract and all isolated compounds showed potent antioxidant activity.
\end{abstract}

Keywords: Acer ginnala var. aidzuense, Acertannin, Gallic Acid, Karakogi-Kaede

\section{Introduction}

The genus Acer, belonging to family Aceraceae has about 200 species worldwide and among them, 26 species are distributed in Japan ${ }^{1}$. Acer ginnala Maxim. var. aidzuense (Franch) Pax (syn. Acer aidzuense (Franch.) Nakai), commonly known as 'Karakogi-kaede' is a deciduous tree about 2-5 m mainly found in wetlands ${ }^{2}$. It is widely distributed in eastern parts of Japan but comparatively rare in western parts including Kyushu Island ${ }^{3}$. It was thought to be extinct for last 30 years in Kumamoto Prefecture, Japan until we recently reported it from Kumagun, Asagiri Town ${ }^{4}$.

Many species of Acer are widely used as traditional medicines in Japan and other countries. For example, the stem bark of Acer nikoense is used for the treatment of hepatic disorders and eye diseases and also as health food $^{5}$. The stem and leaves of Acer palmatum are used in treatment of stomach ache and joint pain ${ }^{6}$. The sap of A. ginnala is used as stomachic and for the treatment of diarrhea ${ }^{7}$. The tea made from young leaves of $A$. ginnala, known as Gao-Cha is used for the prevention of hypertension and inflammation ${ }^{8}$ and also used in treatment of eye problems and headache ${ }^{9}$. These traditional uses suggested that the different plant parts Acer ginnala var. aidzuense may also have some health beneficial effects. In this paper, we report the chemical constituents in the leaves of Acer ginnala var. aidzuense and the antioxidant activity of the extract and isolated compounds.

\section{Materials and Methods}

\subsection{General Experimental Procedures}

Optical rotations were measured with a JASCO DIP1000KUY polarimeter. ${ }^{1} \mathrm{H}-,{ }^{13} \mathrm{C}$ - and $2 \mathrm{D}$-NMR spectra were measured on a JEOL $a-500\left({ }^{1} \mathrm{H}-\mathrm{NMR}: 500 \mathrm{MHz}\right.$ and

\footnotetext{
*Author for correspondence

Email: devkotah@kumamoto-u.ac.jp
} 
${ }^{13} \mathrm{C}$-NMR: $125 \mathrm{MHz}$ ). Chemical shifts are given in ppm with reference to tetramethyl silane (TMS). Absorbance was recorded on Infinite $200 \mathrm{PRO}^{\circ}$ (Tecan Austria $\mathrm{GmBH}$, Grodig, Austria). Column chromatography was carried out with MCI gel CHP20P (75 $150 \mu \mathrm{m}$, Mitsubishi Chemical Industries Co., Ltd., Tokyo, Japan), Sephadex LH-20 (Amersham Pharmacia Biotech, Tokyo, Japan) and Chromatorex ODS (30 $50 \mu \mathrm{m}$, Fuji Silysia Chemical Co., Ltd., Aichi, Japan). TLC was performed on a precoated silica gel $60 \mathrm{~F}_{254}$ (Aluminum sheet, Merck KGaA, Darmstadt, Germany).

\subsection{Chemicals}

1, 1-Diphenyl-2-Picrylhydrazyl (DPPH) and Trolox were purchased from Wako Pure Chemicals, Osaka, Japan, and MES buffer was purchased from Dojindo Chemical Research, Kumamoto, Japan.

\subsection{Plant Materials}

The leaves of Acer ginnala var. aidzuense were collected from Asagiri Town, Kumamoto, Japan in May 2014 and shade dried for one month. The voucher specimens are deposited at the Museum of Traditional Medicines, School of Pharmacy, Kumamoto University.

\subsection{Extraction and Isolation}

The dried leaves (1800 g) were extracted two times with $70 \% \mathrm{MeOH}(8 \mathrm{~L})$ for 48 hours at room temperature. The combined extract was evaporated under reduced pressure to give $406.0 \mathrm{~g}$ extract. A part of the extract (167.0 g) was then subjected on MCI gel CHP20P CC and eluted successively with water, $40 \%, 60 \%, 80 \%$ and $100 \% \mathrm{MeOH}$ to give nine fractions (1 9). Fraction 2 ( $2.6 \mathrm{~g}, 40 \%$ eluate) was subjected to Sephadex LH-20 CC (50\% acetone) and to ODS CC (water, $10 \%, 20 \%$ and $25 \% \mathrm{MeOH}$ ) to afford compounds 1 (84.5 mg), 2 (390.0 $\mathrm{mg}$ ) and 3 (140.5 mg). Fraction 4 (5.4 g, 60\% eluate) was obtained as 3 (5400.0 mg).

\subsection{Gallic acid (1)}

A white amorphous powder; ${ }^{1} \mathrm{H}-\mathrm{NMR}\left(\mathrm{D}_{2} \mathrm{O}\right) \delta_{\mathrm{H}}: 7.17$ $(2 \mathrm{H}, \mathrm{s}, \mathrm{H}-2, \mathrm{H}-6) ;{ }^{13} \mathrm{C}-\mathrm{NMR}\left(\mathrm{D}_{2} \mathrm{O}\right) \delta_{\mathrm{C}}: 174.9(\mathrm{C}-7), 145.2$ (C-3, C-5), 136.9 (C-4), 127.9 (C-1), 110.4 (C-2, C-6).

\subsection{Methyl gallate (2)}

A white amorphous powder; ${ }^{1} \mathrm{H}-\mathrm{NMR}$ $\left(\mathrm{D}_{2} \mathrm{O}\right.$ :acetone- $\left.d_{6}=1: 1\right) \delta_{\mathrm{H}}: 6.98(2 \mathrm{H}, \mathrm{s}, \mathrm{H}-2, \mathrm{H}-6), 3.71$ $\left(3 \mathrm{H}, \mathrm{s}, \mathrm{OCH}_{3}\right) ;{ }^{13} \mathrm{C}-\mathrm{NMR}$ (methanol- $\left.d_{4}\right) \delta_{\mathrm{C}}: 168.9(\mathrm{C}-7)$, 146.2 (C-3, C-5), 139.5 (C-4), 121.3 (C-1), 110.0 (C-2, C-6), $52.2\left(\mathrm{OCH}_{3}\right)$.

\subsection{Acertannin (3)}

A brown amorphous powder; $[\alpha]_{\mathrm{D}}{ }^{20}=+17.0^{\circ}(c=1.0$, acetone); ${ }^{1} \mathrm{H}-\mathrm{NMR}$ (acetone- $\left.d_{6}\right) \delta_{\mathrm{H}}: 7.16,7.18$ (2H each, H-2', H-6', H-2", H-6”), 4.92 (1H, dt, $J=10.0,5.2 \mathrm{~Hz}$, $\mathrm{H}-2), 4.64(1 \mathrm{H}, \mathrm{d}, J=10.8 \mathrm{~Hz}, \mathrm{H}-6), 4.38(1 \mathrm{H}, \mathrm{dd}, J=$ 10.8, 5.2 Hz, H-6), $4.09(1 \mathrm{H}, \mathrm{m}, \mathrm{H}-1), 3.86(1 \mathrm{H}, \mathrm{t}, J=$ $8.9 \mathrm{~Hz}, \mathrm{H}-3), 3.63(2 \mathrm{H}, \mathrm{m}, \mathrm{H}-4$ and $\mathrm{H}-5), 3.40(1 \mathrm{H}, \mathrm{t}, J$ $=9.8 \mathrm{~Hz}, \mathrm{H}-1) ;{ }^{13} \mathrm{C}-\mathrm{NMR}$ (acetone- $d_{6}$ ) $\delta_{\mathrm{C}}: 166.8,167.2$ (C-7', C-7"), 145.8, 145.7 (2C each, C-3', C-5', C-3", C-5”), 138.9, 139.0 (C-4', C-4"), 120.7, 121.0 (C-1', C-1"), 109.7, 109.8 (2C each, C-2', C-6', C-2", C-6"), 79.2 (C-5), 75.9 (C-3), 72.7 (C-2), 71.2 (C-4), 67.1 (C-1), 64.5 (C-6).

\subsection{Free Radical Scavenging Activity}

The DPPH radical-scavenging activity of extract and isolated compounds was examined using the method reported previously ${ }^{10}$ with slight modifications. Briefly, 50 $\mu \mathrm{L}$ of $200 \mathrm{mM}$ MES [2-( $N$-morpholino) ethanesulphonic acid] buffer ( $\mathrm{pH}$ 6.0), $100 \mu \mathrm{L}$ of samples with different concentrations (in DMSO:Ethanol $=1: 1$ ) and $50 \mu \mathrm{L}$ of $800 \mathrm{mM}$ DPPH in ethanol solution were mixed in a 96well plate and kept in dark at room temperature for 20 minutes. The anti-oxidative activity corresponding to the scavenging of DPPH radicals was measured at $510 \mathrm{~nm}$ with UV spectrophotometer using following formula: Radical scavenging activity $(\%)=100 \times(\mathrm{A}-\mathrm{B}) / \mathrm{A}$. Where, $\mathrm{A}$ is the control absorbance of DPPH radicals without samples and $\mathrm{B}$ is the absorbance after reacting with samples. Trolox was used as the positive control. The result is expressed as mean of three experiments. From these data, curve was plotted and concentration $((\mu \mathrm{g} / \mathrm{mL}$ or $\mu \mathrm{M})$ ) of the sample required for $50 \%$ reduction of the $\mathrm{DPPH}$ radical absorbance $\left(\mathrm{EC}_{50}\right)$ was calculated.

\section{Results and Discussion}

Since, we have reported Acer ginnala var. aidzuense from Kumamoto after many years, the main aim of this study 


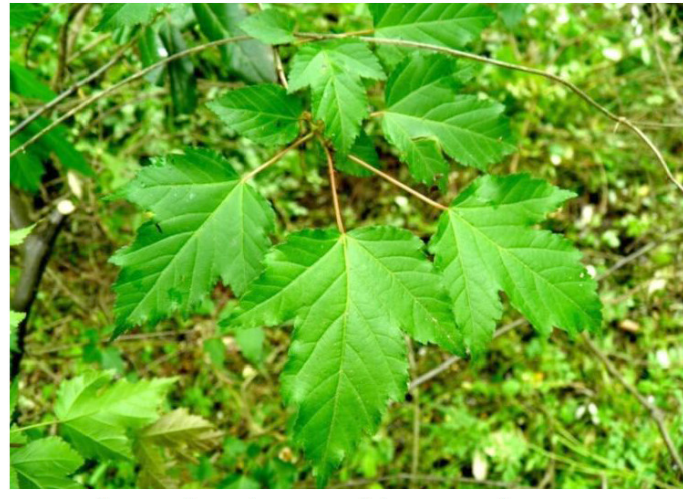

Acer ginnala var. aidzuense leaves<smiles>O=C(O)c1cc(O)c(O)c(O)c1</smiles>

gallic acid (1)<smiles>CC(=O)c1cc(O)c(O)c(O)c1</smiles>

methyl gallate (2)

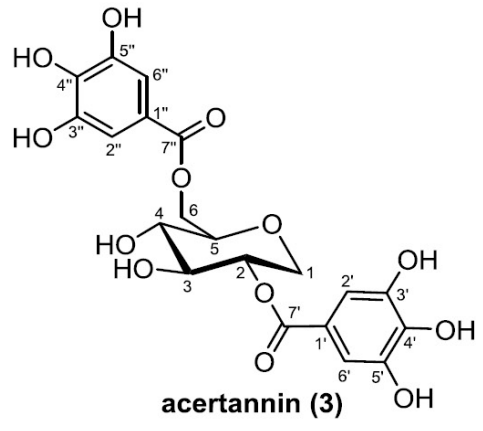

acertannin (3)

Fig. 1. Compounds isolated from the leaves of Acer ginnala var. aidzuense.

was to identify the chemical constituents in the leaves of title plant and evaluate the antioxidant activity. Three phenolic compounds namely, gallic acid $(\mathbf{1})^{11}$, methyl gallate $(2)^{11}$ and acertannin (3) $)^{12}$ (Figure 1) were isolated from the $70 \% \mathrm{MeOH}$ extract of the leaves. Structures of these compounds were elucidated on the basis of NMR spectra and comparison with literature data.

The $70 \% \mathrm{MeOH}$ extract and all of the isolated compounds were tested for their in vitro antioxidant activity towards DPPH free radical scavenging assay. The concentrations of the sample required for $50 \%$ reduction of the DPPH radical absorbance ( $\mathrm{EC}_{50}$ values) are given in Table 1. The results were compared with Trolox as positive control. The $70 \% \mathrm{MeOH}$ extract $\left(\mathrm{EC}_{50}, 7.0 \mu \mathrm{g}\right)$ showed more potent activity than Trolox $\left(\mathrm{EC}_{50}, 12.2\right.$ $\mu \mathrm{g})$. Among the isolated compounds, the activity of acertannin (3) was the strongest $\left(\mathrm{EC}_{50}, 8.6 \mu \mathrm{M}\right)$ followed by gallic acid (1) $\left(\mathrm{EC}_{50}, 12.9 \mu \mathrm{M}\right)$ and methyl gallate (2) $\left(\mathrm{EC}_{50}, 13.0 \mu \mathrm{M}\right)$, and all of these compounds were more potent as compared to Trolox $\left(\mathrm{EC}_{50}, 48.8 \mu \mathrm{M}\right)$. These findings are similar to previous studies on Acer plants and their bioactivities ${ }^{8,12}$.

Table 1: $\mathrm{EC}_{50}$ values of extract, compounds and Trolox

\begin{tabular}{lcl}
\hline Samples & $\mathrm{EC}_{50}(\mu \mathrm{g} / \mathrm{ml})$ & $\mathrm{EC}_{50}(\mu \mathrm{M})$ \\
\hline $70 \% \mathrm{MeOH}$ extract & 7.0 & - \\
gallic acid (1) & 2.2 & 12.9 \\
methyl gallate (2) & 2.4 & 13.0 \\
acertanin (3) & 4.0 & 8.6 \\
Trolox & 12.2 & 48.8 \\
\hline
\end{tabular}

Thus, these results suggest that the leaves of Acer ginnala var. aidzuense contain highly antioxidant phenolic compounds including gallic acid, methyl gallate and acertannin. The consumption of the tea made from the leaves may have preventive effects against damage caused by oxidative stress. However, more studies are required for the quantitative estimation of these compounds and in vivo biological activities of extracts and individual compounds.

\section{Acknowledgements}

We are grateful to Ms. Teruo Tanaka of Institute of Resource Development and Analysis, Kumamoto University for measurement of NMR measurements. This work was supported in part by Program for Leading Graduate Schools, Health life science: Interdisciplinary and Glocal Oriented (HIGO) Program, MEXT, Japan.

\section{References}

1. Satake Y, Hara H, Watari S, Tominari T. Wild flowers of Japan woody plants. Tokyo: Heibonsha Ltd; 1989. p. 7.

2. Ogata K. A dendrological study on the Japanese Aceraceae, with special reference to the geographical distribution. Bulletin of the Tokyo University Forests. 1965; 60:1-99.

3. Igari T. The handbook of Japanese Maples. Tokyo: Bun-ichi Co Ltd; 2010. p. 84.

4. Watanabe M, Sato C, Kariyazaki T, Yahara S. Report on Karakogi-kaede in Kumamoto Prefecture (in Japanese), Botany. 2014; 64:1-5. 
5. Morikawa T, Tao J, Ueda K, Matsuda H, Yoshikawa M. Medicinal foodstuffs. XXXI. Structures of new aromatic constituents and inhibitors of degranulation in RBL2H3 cells from a Japanese folk medicine, the stem bark of Acer nikoense. Chemical and Pharmaceutical Bulletin. 2003; 51:62-7. https://doi.org/10.1248/cpb.51.62 PMid:12520130

6. Xiao PG. A pictorial encyclopedia of Chinese medical herbs. Tokyo: Chuokoron-Sha, Inc; 1993. p. 135.

7. Choi YH, Han SS, Lee HO, Baek SH. Biological activity of bioactive components from Acer ginnala Max. Bulletin of the Korean Chemical Society. 2005; 26:1450-52. https:// doi.org/10.5012/bkcs.2005.26.9.1450

8. Lu R-L, Hu F-L, Xia T. Activity-guided isolation and identification of radical scavenging components in GaoCha Tea. Journal of Food Science. 2010; 75:H239-43. https://doi.org/10.1111/j.1750-3841.2010.01804.x PMid:21535501
9. Xiao PG. A pictorial encyclopedia of chinese medical herbs. Tokyo: Chuokoron-Sha, Inc; 1993. p. 106.

10. Joshi KR, Devkota HP, Watanabe T, Yahara S. Thotneosides A, B and C: Potent antioxidants from Nepalese crude drug, leaves of Aconogonon molle. Chemical and Pharmaceutical Bulletin. 2014; 62:191-95. https://doi. org/10.1248/cpb.c13-00748 PMid:24292866

11. Kumaran A, Karunakaran RJ. Nitric oxide radical scavenging active compounds from Phyllanthus embellica L. Plant Foods for Human Nutrition. 2006; 61:1-5. https:// doi.org/10.1007/s11130-006-0001-0 PMid:16688481

12. Hatano T, Hattori S, Ikeda $\mathrm{Y}$, Shingu $\mathrm{T}$, Okuda $\mathrm{T}$. Gallotannins having a 1,5-anhydro-D-glucitol core and some ellagitannins from Acer species. Chemical and Pharmaceutical Bulletin. 1990; 38:1902-5. https://doi. org/10.1248/cpb.38.1902 